\title{
THE INFLUENCE OF PLASTIC PROPERTIES OF COAL BLENDS ON EVOLUTION OF REFLECTANCE INDICATING SURFACE (RIS) PARAMETERS OF COKES
}

\author{
Lukasz Smędowski \\ Institute for Chemical Processing of Coal, Zamkowa Str. 1, 41-800 Zabrze.E-mail: lsmedowski@ichpw.zabrze.pl
}

\begin{abstract}
The aim of this work was to characterize cokes optical texture influence of plastic properties of coal blends on degree of cokes optical texture ordering. Three samples of coal blend characterized by different composition and properties were pyrolysed in Karbotest furnace (laboratory scale). To characterize plastic properties of the blends studied, temperatures at the beginning, maximum and at the end of plasticity $\left(t_{1}, t_{\max }\right.$ and $t_{3}$, respectively) were determined as well as maximum fluidity $\mathrm{F}_{\max }$. Texture of resultant cokes was determined by means of optical microscopy. As the result of these studies a set of optical parameters that describe reflectance indicating surface such as maximum, intermediate and minimum reflectance $\left(R_{M A X}, R_{I N T}, R_{M I N}\right.$ respectively) as well as values of Killby' transformates $\left(R_{\text {st, }}, R_{a m}\right.$, $R_{\mathrm{ev}}$ ) were determined for each sample. The optical texture parameters of the cokes were discussed in relationship to plastic properties of coals blends. Correlation between cokes anisotropy and fluidity of initial blends was detected.
\end{abstract}

Keywords:.coal blends, coke, optical texture, plasticity.

\section{Introduction}

Cokes manufactured at high temperatures (HTs) are used in the steel industry for the reduction of iron ore to pig iron in blast furnaces. Fabrication of such metallurgical cokes, needs a large amount of very good coking coals because the very good quality of this product is required. Unfortunately, sources of these coals are running low, which strongly increases their price. Thus, efficiency of very good caking coal exploitation is an important task for both users and researchers (Hereźniak \& Warzecha, 2009).

Some solution of the problem is using low-quality coking coals instead of a part of expensive good coals. Good coking coal and one or two coals with lower caking ability are mixed to create a blend and next are pyrolyzed in a coking chamber. Components heated to HTs affect each other in many different ways, dependent upon many factors, such as values of their fluidity parameters: fluidity, $F_{\max }$, softening temperature, $t_{1}$, temperature of maximal fluidity, $\mathrm{t}_{\max }$, and resolidification temperature, $\mathrm{t}_{3}(\mathrm{Sa}-$ kurovs, 2003). These mutual interactions of coals in a blend are very complex. Coals contain volatile matter that can be moved from the first softening coal in a blend and stored in pores of the other coals of higher softening temperature, $t_{1}$ (Krzesińska et al. 2011). Captured volatiles from lower quality coking coals may plasticize other components of a blend, which results that there are good conditions for the evolution of structure, microtexture and mesophase optical texture of cokes (Smędowski \& Krze- sińska, 2012). Texture of cokes can be described by parameters of reflectance indicating surface (RIS) which comprehensive characterizes optical properties of cokes (Killby, 1988). Summarizing, degree of ordering of optical texture that is a fingerprint of blend features and condition of pyrolysis could be strongly dependent of fluidity parameters of initial blends.

The aim of this work was to characterize optical anisotropy of three coke samples and to check it relation to thermoplastic properties of their initial coal blends. To obtain full information about cokes' texture optical parameters of reflectance indicating surface (RIS) such as maximum, intermediate and minimum reflectance $\left(R_{M A X}\right.$, $\mathrm{R}_{\mathrm{INT}}, \mathrm{R}_{\mathrm{MIN}}$ respectively) as well as values of Killby' transformations $\left(R_{s t}, R_{a m}, R_{e v}\right)$ were determined for each sample with use of modified Killby's method (Duber et al. 2000, Smędowski et al. 2008).

\section{Experimental}

The studies were performed on three initial coal blends and their cokes. Basic parameters of blends are presented in Table 1. It can be seen that all these samples have similar both rank measured by volatile matter content and caking properties determined with swelling index SI. They differ only with fluidity - samples B1 and B2 are characterized by lower values of $F_{\max }$ than sample B3. Such set of blends allow checking the influence of thermoplastic properties on textural features of cokes. The plastic properties of the blends presented by $t_{1}$ - the sof- 
tening temperature, $t_{3}$ - the resolidification temperature, $\mathrm{t}_{\max }$ - the temperature of maximal fluidity and $\mathrm{F}_{\max }-$ the value of maximal fluidity were determined using Frico Gieseler plastometer according to ASTM D 2639.

Table 1. Basic characteristics of coal blends studied

\begin{tabular}{|l|c|c|c|}
\hline Sample name & B1 & B2 & B3 \\
\hline Moisture content, $\%$ & 8,8 & 8,4 & 8,2 \\
\hline Volatile matter content, \% & 27,4 & 27,9 & 28,5 \\
\hline SI & 7 & 7 & 7,5 \\
\hline $\begin{array}{l}\text { Temperaturę at the begining } \\
\text { of plasticity, } \mathbf{t}_{\mathbf{1}}{ }^{\circ} \mathbf{C}\end{array}$ & 399 & 402 & 402 \\
\hline $\begin{array}{l}\text { Temperaturę at the maximum } \\
\text { of plasticity, } \mathbf{t}_{\max },{ }^{\circ} \mathbf{C}\end{array}$ & 450 & 446 & 448 \\
\hline $\begin{array}{l}\text { Temperaturę at the end } \\
\text { of plasticity, } \mathbf{t}_{\mathbf{3}}{ }^{\circ} \mathbf{C}\end{array}$ & 484 & 479 & 480 \\
\hline Maximum plasticity. $\mathbf{F}_{\text {max }}, \mathbf{d d p m}^{\mathbf{d}}$ & 276 & 249 & 564 \\
\hline
\end{tabular}

Coking process was carried out in the apparatus Karbotest. It is a vertical tubular oven for producing metallurgical coke under laboratory conditions being close to industrial scale. The coal blend weighing $5000 \mathrm{~g}$, with the grain size $\leq 3 \mathrm{~mm}$ and bulk density of $850 \mathrm{~kg} / \mathrm{m}^{3}$ was placed in a steel retort (depth $370 \mathrm{~mm}$, inner diameter 130 $\mathrm{mm})$. The retort was put into the hot oven with the temperature of about $950{ }^{\circ} \mathrm{C}$ and it was heated up for about $180 \mathrm{~min}$ till the temperature in the middle of the charge reached $950{ }^{\circ} \mathrm{C}$.

Microscopic characteristics of coke samples were determined with reflected light optical microscope AxioImager M1m (Carl Zeiss, Germany) using monochromatic plane polarized light of $\lambda=546 \mathrm{~nm}$. Coke grains of $\leq 3.0 \mathrm{~mm}$ diameter were embedded in epoxy resin and polished according to the procedure recommended by the International Committee for Coal Petrology (Davis, 1998). The apparent maximum ( $R_{\max }$ ) and minimum $\left(R^{\prime}{ }_{\text {min }}\right)$ reflectance values were automatically measured on randomly oriented, fused coke grains, in immersion oil, at the magnification $500 \times$.

\section{Results and discussion}

Values of $\mathrm{R}_{\text {max }}$ and $\mathrm{R}_{\text {min }}$ of all cokes samples are presented on Fig. 1. It can be seen that $\mathrm{R}_{\text {max }}$ and $\mathrm{R}_{\text {min }}$ data sets overlap one another for all samples studied. Such overlapping for cokes is not suprizing because of heterogeneity of initial coals. Sample B1 (Fig. 1a) is characterized by lower values of maximum reflectance than both samples B2 and B3 (Fig. 1b and 1c). It can be also noticed that sample B3 has the highest minimum and maximum values of optical bireflectance define $\mathrm{R}_{\text {max }}-$ $\mathrm{R}_{\text {min. }}$ Basing on these three cross-plots we can suppose that the coke B3 that was manufactured from a blend with the highest $F_{\max }$ has the best ordered texture among all cokes studied. But any quantitative analysis cannot be performed at the base of "raw" plots due to heterogeneity of these cokes.
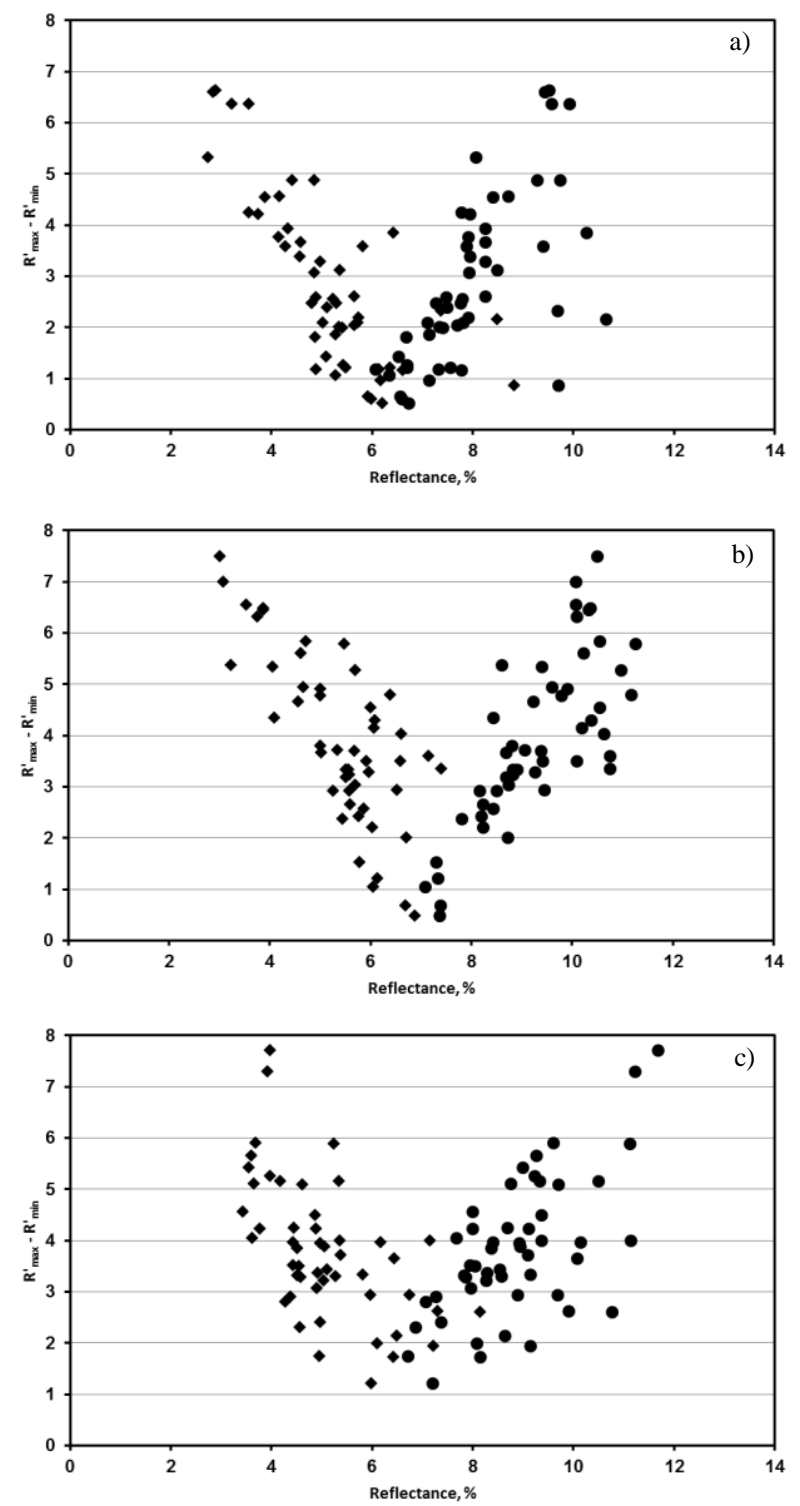

Fig. 1. Measured values of maksimum and minimum reflectances for samples: a) B1, b) B2, c) B3.

Notation: • - $\mathrm{R}_{\text {max }}, \bullet-\mathrm{R}_{\text {min }}^{\prime}$

To accurate determination of RIS parameters a modified Killby's method was used. Values of R' ${ }_{\text {max }}$ and R' min $_{\text {mere }}$ processed with SELEKCJA programme (Duber et al. 2000). At a result average values of $R_{M A X}, R_{I N T}, R_{M I N}$ were determined as well as values of Killby's transformates: $R_{\mathrm{st}}, \mathrm{R}_{\mathrm{ev}}$ and $\mathrm{R}_{\mathrm{am}}$. Results of calculations are presented in Table 2.

Table 2. Values of reflectance parameters of cokes studied.

\begin{tabular}{|c|c|c|c|c|c|c|c|}
\hline & $\begin{array}{c}\mathbf{R}_{\text {MAX }}, \\
\mathbf{\%}\end{array}$ & $\begin{array}{c}\mathbf{R}_{\text {INT, }}, \\
\mathbf{\%}\end{array}$ & $\begin{array}{c}\mathbf{R}_{\text {MIN }}, \\
\boldsymbol{\%}\end{array}$ & $\mathbf{R}_{\text {st }}$ & $\mathbf{R}_{\text {ev }}$ & $\mathbf{R}_{\text {am }}$ & $\begin{array}{c}\mathbf{R}_{\text {bi }} \\
\mathbf{\%}\end{array}$ \\
\hline B1 & 8.92 & 7.12 & 2.98 & -12.2 & 5.7 & 0.18 & 5.94 \\
\hline B2 & 10.22 & 7.44 & 3.76 & -7.2 & 6.4 & 0.17 & 6.46 \\
\hline B3 & 10.73 & 7.76 & 3.27 & -7.2 & 6.5 & 0.20 & 7.46 \\
\hline
\end{tabular}


For B1 sample three classes of texture were determined while for both B2 and B3 samples only two classes were defined. It means that the degree of heterogeneity is higher for coke B1 than for other samples studied. Values of both $\mathrm{R}_{\mathrm{MAX}}$ and $\mathrm{R}_{\mathrm{INT}}$ increase in the order: from $\mathrm{B} 1$ sample to $\mathrm{B} 3$ sample while $\mathrm{R}_{\mathrm{MIN}}$ changes in other way - it is lowest for B1 sample and highest for B2 sample. It means that the coke B3 is characterized by highest degree of optical anisotropy, defined by difference $R_{M A X}-R_{M I N}$, and the highest degree of texture ordering. Values of $R_{a m}$ parameter confirm this conclusion - an elongation of RIS (Fig. 2) determined by this parameter is largest for sample B3.

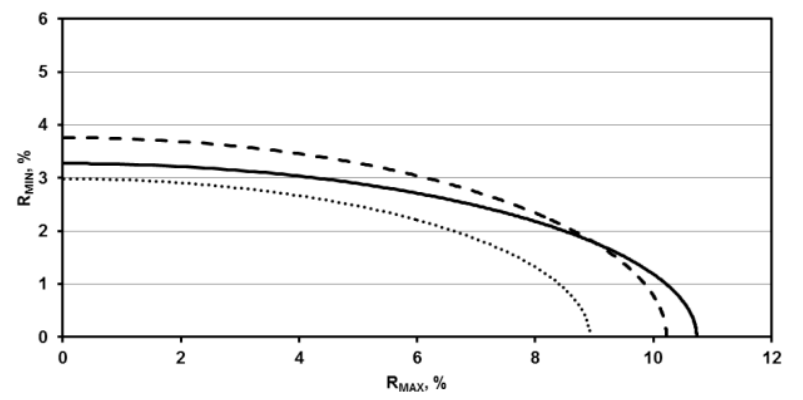

Fig. 2. Reflectance Indicating Surfaces for studied samples of cokes. Notation: continuous line - coke B3, dashed line - coke B2, dotted line - coke B1.

Values of $\mathrm{R}_{\mathrm{st}}$ for all samples studied indicate that their optical character is biaxial negative and this is known feature of thermally treated carbon materials (Pusz \& Duber, 1998).

Results of reflectance analyses of cokes were compared with thermoplastic properties of initial blends. Fig. 3 presents relationship between $\mathrm{R}_{\mathrm{am}}$ parameter and maximum fluidity, $\mathrm{F}_{\max }$. It can be seen that cokes anisotropy increase with fluidity of blends in the range from 200 to $600 \mathrm{ddpm}$ and the coefficient of linear trend is $r=0.92$. Basing on this relationship it can be assumed that higher plasticized blends are good precursors for well-ordered cokes. Despite of this we can suppose that coke anisotropy decreases for higher values of fluidity. This is caused because of that high fluidity is connected with higher contribution of medium or high volatile content of medium or high volatile bituminous coal in a blend. Cokes performed from such blends, which are characterized by poor caking properties, has poorly ordered texture. Summarizing, we can conclude that obtained correlation is proper only in the limited range of fluidity of initial blends.

Coke anisotropy can be also described with use of maximum and minimum reflectances. Fig. 4 shows relationship between bireflectance, $\mathrm{R}_{\mathrm{bi}}$ and maximum fluidity, $\mathrm{F}_{\max }$. Correlation coefficient is also high, $\mathrm{r}=0.91$ and it indicates that plastic properties of initial blends affect both $\mathrm{R}_{\mathrm{MAX}}$ and $\mathrm{R}_{\mathrm{MIN}}$. It can be simply explained - optical properties of cokes are reflection of their molecular structure and microtexture. It is known that small basic structural units have tendency to arrange and form larger objects called molecular oriented domains. Degree of such arrangement depends among other things on fluidity there are better conditions to forming microtexture when the fluidity is higher. The degree of microtextures ordering is reflected by minimum and maximum reflectanses. Of course, such mechanism is true only in limited range of fluidity, as it was mentioned above.

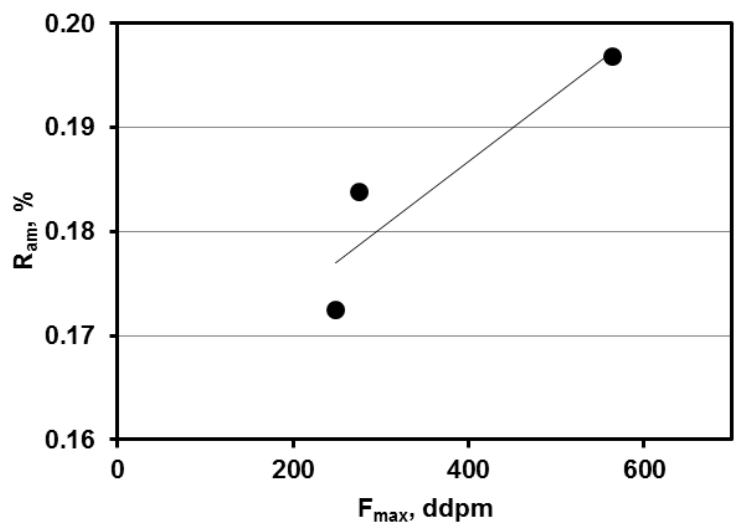

Fig. 3. Relationship between coke anisotropy, $R_{a m}$ and fluidity of initial blends, $F_{\max }$. Straight line shows a trend, $\mathrm{r}=0.92$.

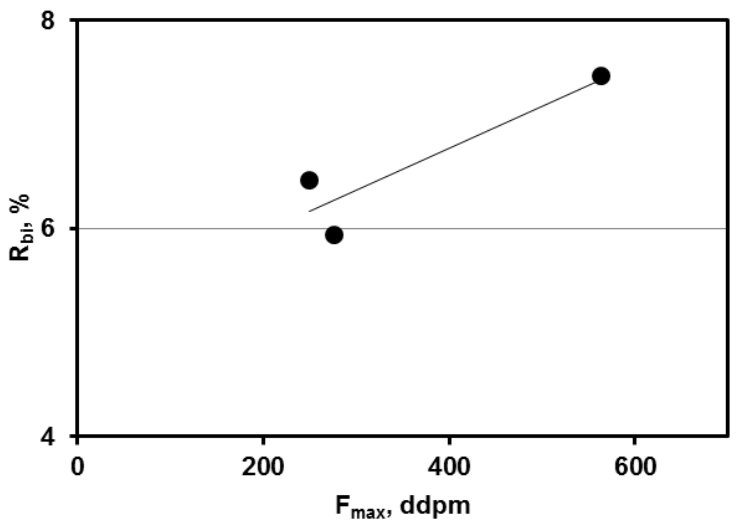

Fig. 4. Relationship between coke bireflectance, $R_{b i}$ and fluidity of initial blends, $\mathrm{F}_{\max }$. Straight line shows a trend, $\mathrm{r}=0.91$.

\section{Conlusions}

Optical properties of coke were described as well as the influence of plastic properties of initial blends on them. The conclusions are as follows:

- Studied coke samples are characterized by heterogenity of optical properties. There are three classes of optical texture for sample B1 and two classes of texture for booth B2 and B3 cokes,

- The fluidity of initial blends affects cokes anisotrophy in the range from $200 \mathrm{ddmp}$ to 600 ddpm - the higher is $F_{\max }$, the higher is value of anisotropy parameter e.g. $R_{a m}$ and $R_{b i}$. 


\section{Acknowledgments}

This study was financed under the Smart Coking Plant R\&D Project (Innovative Economy Programme (POIG), Contract no 01.01.02.-24-017/08).

\section{References}

Davis, A., (1998) Methods and procedures. In: Taylor, G.H, Teichmuller, M., Davies, A., Diessel, C.F.L., Littke, R., Robert,P. (Eds) Organic petrology, Gebruder Borntraeger, Berlin - Stutgart.

Duber, S., Pusz, S., Kwiecińska, B. K., Rouzaud, J.-N. (2000) On the optically biaxial character and heterogeneity of anthracites, International Journal of Coal Geology, 44, 227 - 250.

Hereźniak, W., Warzecha, A. (2009) Międzynarodowy rynek węgla koksowego i koksu - stan obecny i prognozy rozwoju, Karbo, 4, 197 - 206.

Kilby, W. E. (1988) Recognition of vitrynite with nonuniaxial negative reflectance characteristics, International Journal of Coal Geology, 9, 267 - 285.

Krzesińska, M,. Smędowski, Ł., Szeluga, U., Majewska, J. (2011) Rheological properties of coal blends with varying content of strongly caking coal studied by means of Dynamic Mechanical Analysis (DMA) and Gieseler plastometer. In: Proceedings of 63th Meeting of the International Committee for Coal and Organic Petrology (ICCP), Porto, 53-54.
Pusz. S., Duber, S. (1998) Changes of optical properties of carbon materials during thermal treatment. In: Proceedings of Conference of Science and Technology of Carbon, Strasbourg, 793-794.

Smędowski, Ł., Krzesińska, M. (2012) Wpływ właściwości plastycznych mieszanek węglowych na strukturę otrzymanych koksów, Karbo, 1, 30 - 38.

Smędowski, Ł., Duber, S., Pusz, S. (2008) Badanie mikrotekstury węgli kamiennych i koksów, Karbo, 3, 134-141

\begin{abstract}
Abstrakt
Celem niniejszej pracy było scharakteryzowanie tekstury optycznej koksów oraz wpływu właściwości plastycznych wyjściowych mieszanek na parametry opisujące teksturę. Trzy mieszanki węglowe o zróżnicowanym składzie i właściwościach plastycznych zostały skoksowane w instalacji Karbotest. Właściwości plastyczne określono wartościami temperatur: począt$\mathrm{ku}$, maksimum i końca plastyczności (odpowiednio: $\mathrm{t}_{1}, \mathrm{t}_{\max }$ and $\mathrm{t}_{3}$ ) oraz wskaźnikiem maksymalnej plastyczności $\mathrm{F}_{\max }$. Tekstura tak otrzymanych koksów została zbadana z zastosowaniem mikroskopii optycznej. W wyniku badań określono wartości maksymalnej, pośredniej i minimalnej refleksyjności (odpowiednio: $R_{M A X}, R_{I N T,} R_{M I N}$ ) oraz wartości parametrów transformacji Killby'ego $\left(R_{s t}, R_{a m}, R_{e v}\right)$. Parametry optyczne charakteryzujące teksturę zostały skorelowane z parametrami określającymi właściwości plastyczne. Stwierdzono występowanie zależności pomiędzy anizotropią koksu i maksymalną plastycznością mieszanki wejściowej.
\end{abstract}

Słowa kluczowe: mieszanki węglowe, koks, tekstura optyczna, plastyczność

\section{INNOWACYJNA GOSPODARKA} NARODOWA STRATEGIA SPÓJNOŚCI
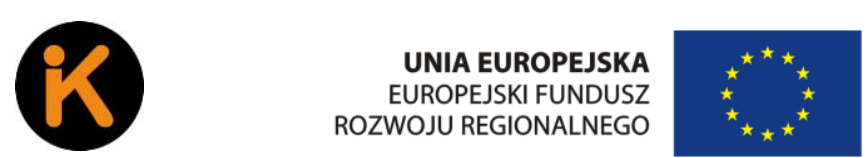